\title{
An Overview of the Administrative Issues in Preschools from Preschool Teachers' Perspectives
}

\author{
Muhammet Ü. Öztabak ${ }^{1} \&$ Duygu Yalman Polatlar ${ }^{2}$ \\ ${ }^{1}$ Faculty of Education, Department of Educational Sciences, Fatih Sultan Mehmet Vakif University, Istanbul, \\ Turkey \\ ${ }^{2}$ Faculty of Education, Department of Early Childhood Education, Fatih Sultan Mehmet Vakif University, \\ Istanbul, Turkey \\ Correspondence: Duygu Yalman Polatlar, Faculty of Education, Department of Early Childhood Education, Fatih \\ Sultan Mehmet Vakıf University, Istanbul, Turkey. E-mail: dyalman@fsm.edu.tr
}

Received: October 5, 2020 Accepted: November 9, 2020 Online Published: November 26, 2020

doi:10.5539/jel.v9n6p183 URL: https://doi.org/10.5539/jel.v9n6p183

\begin{abstract}
The aim of the current study was to review some of the administration issues at preschools from preschool teachers' perspectives by employing a holistic, multiple-case design. Ten preschool teachers working in state-funded preschools in the Anatolian Side of Istanbul during Fall 2019 and Spring 2020 made up the sample of the study. The data collected from the participants through face-to-face interviews were divided into three themes, which are physical structure, staff and administration. Descriptive statistics were performed. The results revealed that architectural deficiencies in the physical structure, ineffective leadership in the workplace, problems with joint planning and consultation, inexperienced support staff, fees, interfering parents or guardians, double shift schooling and superficial approach to supervision were among the outstanding problems reported by the preschool teachers.
\end{abstract}

Keywords: preschool education, management, school administration, preschool teachers, administration issues

\section{Introduction}

Preschool education aims to support all the developmental areas of children aged 0-72 months and prepare them for primary school and life. The education provided for preschoolers should be developmentally appropriate and delivered in a stimulating environment (Oguzkan \& Oral, 1983). Oktay (2006) emphasize that preschool education should teach children to respect others' and their own rights while expressing their views and feelings freely.

Preschool is a period that makes significant contributions to 3-6-year-old children's development by getting them ready for the first grade, which is the first step of the formal education. Whether parents and children have positive and constructive experiences during the preschool education is of utmost importance because it is this very place where children start to develop or lose their confidence and feelings of safety and trust, which will accompany them throughout their school years (Katranci, 2014).

Preschools are structurally different from other grades with respect to objectives, staff and the age groups they serve (Bute \& Balci, 2010). Larkin (1999) compared preschools and other grades with respect to structure and relations and concluded that preschools often have a broader hierarchy where it is easier to contact administration (as cited in Bute \& Balci, 2010). In other words, teachers and administrative staff work closely together in an interactive environment. Therefore, even the littlest problem can have direct impacts on the whole system.

The relationships and interactions between school administrators and teachers as well as school-home, school-public relationships is one of the determinants of a quality education (Cinkir \& Cetin, 2010), which requires a careful planning and selection of physical conditions, program and staff (Oktay, 1999).

School management cannot exist without others and there are several factors affecting it (Ebabil, 2015). Administrators and teachers play the biggest part in achieving the goals of early childhood education. The problems in administration might have some negative consequences for educational practices, which may impede the goals of preschool education (Tok, 2002). 
A systematical approach was developed based on the reflections of the administrative staff at the Children's Center in the University of South Carolina on their expectations, responsibilities and conditions. A guide was developed focusing on the management skills and leadership abilities as summarized below (Freeman \& Brown, 2000):

Management skills:

1) The ability to develop and maintain an affective organization, including goal setting, strategic planning, resource allocation, and on-site problem solving.

2) The ability to plan and implement administrative systems that effectively carry out the program's mission, goals, and objectives, including oversight of all programs for children.

3) The ability to manage personnel, conduct productive staff evaluations, and oversee staff development.

4) The ability to plan and maintain an appropriate learning facility.

5) Knowledge of legal, licensing and budgetary regulations necessary for effective management. Leadership abilities:

1) Knowledge of National Association for the Education of Young Children (NAEYC) Code of Ethical Conduct and the ability to use it.

2) An awareness of one's own personal learning and teaching styles and the ability to apply this knowledge to working with young children, their families, and their caregivers.

3) The ability to translate knowledge of child development and appropriate curriculum design into quality programs for children.

4) The ability to cultivate productive relationships within a diverse community and to assume an appropriate advocacy role.

5) The ability to develop, articulate, and pursue a personal and programmatic vision.

There have always been problems and conflicts in any place where humans exist no matter how much emphasis is put on teachers' and managers' responsibilities. Zembat (2012) summarizes the conflicts between the teachers and managers as follows:

1) Managers requiring teachers to prepare and do activities that all children participate for ceremonies.

2) Managers being insensitive to the needs for materials, physical environment and support staff.

3) Managers having the control of the fees collected from parents to meet children's needs but using them for other expenses.

4) Managers and parents/guardians lacking knowledge about preschool education.

5) Managers not treating all teachers equally.

Schools are similar to big families and organizations where the joy or learning and teaching is shared among students, teachers, school administrators and parents. The harmony in this family requires a precise and systematic communication in each part of the organization (Beaudoin \& Taylor, 2004). The expectations of teachers from managers in preschools are often different from those of primary, elementary or high school teachers as the running and structure of preschools differ from other levels. Therefore, possessing general management skills may not be sufficient for managing preschools which requires specific knowledge and experience with children for a quality education targeting children's needs and teachers' expectations (Kuyucak, 2013).

The aim of the present study is to review administration issues in preschools from preschool teachers' perspectives. The results will reveal the perspectives on preschool education and offer some solutions to the existing problems that might improve the quality of preschool education.

\section{Method}

\subsection{Research Model}

A case study design was employed as it supports the exploratory aims of the present study. A case study is a research method to seek answers to scientific questions where a phenomenon is defined based on time and space (Buyukozturk et al., 2008). What makes a qualitative case study distinct is that it focuses on how a phenomenon affects a state and how it is affected by that state. A holistic, multiple cases study design is adopted in the current study as there are multiple cases each of which can be analyzed as a whole. Each case is examined as a whole 
first and them compared and contrasted with the others (Yildirim \& Simsek, 2013).

\subsection{Participants}

Ten preschool teachers working in state-funded preschools in the Anatolian Side of İstanbul during Fall 2019 and Spring 2020 made up the sample of the study. Purposive sampling and convenience sampling methods were used to retrieve the participants. Purposive sampling is used when researchers select the participants who are more likely to fit the purpose of the study. Convenience sampling is used when researchers have limited resources. In addition, working with a familiar population might be perceived as a more practical and easier method for some researchers, which might speed up the pace of the research (Yildirim \& Simsek, 2013).

Teacher demographics are presented in Table 1.

Table 1. Participant demographics

\begin{tabular}{llllll}
\hline Teacher & Gender & Age & Education Level & Tenure on the Job & Type of School \\
\hline T1 & W & 30 & Bachelor's & 5 & Kindergarten \\
T2 & W & 34 & Bachelor's & 10 & Preschool \\
T3 & W & 40 & Bachelor's & 15 & Preschool \\
T4 & W & 28 & Bachelor's & 3 & Kindergarten \\
T5 & W & 42 & Bachelor's & 17 & Preschool \\
T6 & W & 32 & Bachelor's & 8 & Preschool \\
T7 & W & 26 & Bachelor's & 2 & Kindergarten \\
T8 & W & 37 & Bachelor's & 13 & Kindergarten \\
T9 & W & 29 & Bachelor's & 4 & Preschool \\
T10 & W & 39 & Bachelor's & 16 & Kindergarten \\
\hline
\end{tabular}

All the participants were women and had a bachelor's degree. Fifty percent of the participants worked at kindergartens while the rest of them worked in preschools. Their tenure on the job ranged between 2 and 16 with an average of 9.3 years.

\subsection{Data Collection Tools}

The data was collected with the semi-structured interview forms developed by the researchers. An extensive body of literature was reviewed for the interview questions to ensure the content validity of the data collection tool. Twelve questions were formed and reviewed by three experts for their clarity, adequacy and scope. Based on the feedback from the experts, some questions were removed, some were extended and some of them were revised. The number of the interview questions was reduced to eight under three main themes, which are as follows:

a. Questions related to physical structure

1) What do you think about the physical structure of the school you are working at?

b. Questions related to staff

1) What responsibilities principals and vice principals at your school should have?

2) What do you think about the functioning of the teacher groups (all teachers in a school teaching the same subject) at your school? What kind of a work schedule do you follow?

3) How do you evaluate the work of the support staff at your school? What are your criteria for hiring support staff?

c. Questions related to school administration

1) Could you tell us about your experiences with the collection of fees? What are the biggest expenditure items on your school budget?

2) Does the socioeconomic status of the neighborhood where your school is located affect your work and activities in your classes? Do you do anything to improve the conditions?

3) What do you think about the supervision at your school?

4) What do you think about the working hours at your school?

\subsection{Data Collection}

The data were collected through the face-to-face interviews with the teachers who volunteered to participate. The 
teachers were interviewed after the classes in teachers' room or guidance service room with the permission of the school administrators. The researchers introduced themselves, informed the teachers about the aim and scope of the study and tried to build a good rapport with them. The interviews, which lasted about 40 minutes each, were recorded and the researchers took notes during the interviews. Teachers were coded T1, T2, etc. for confidentiality.

\subsection{Data Analysis}

Descriptive analysis was used to analyze and interpret the responses of the participants following the stages below:

1) Nomenclature,

2) Elimination,

3) Development of categories,

4) Ensuring reliability and validity,

5) Calculation and interpretation of frequencies (Yildirim \& Simsek, 2013).

\subsection{Validity and Reliability}

Reporting on the data collection in detail to explain how the results are obtained is an important factor to ensure the validity of a qualitative research (Yildirim \& Simsek, 2005). The data analysis process in explained in the current study to enhance the validity of the results. The responses representing the categories are discusses in the findings section.

The responses of the participants were rated and interpreted separately by each researcher to ensure reliability. Then, the sub-themes developed from these evaluations were compared to reach a consensus. The formula suggested by Miles and Huberman (2016) was used to ensure reliability:

Reliability $=$ Number of Agreements / (Number of Agreements + Disagreements)

$75 \%$ agreement between the coders was considered sufficient to ensure consistency in the present study.

\section{Findings}

The analysis of the findings of the interviews revealed the themes presented in Table 2 .

Table 2. Themes and sub-themes

\begin{tabular}{ll}
\hline Themes & Sub-themes \\
\hline Physical Structure & Architectural design \\
Staff & Leadership \\
& Joint planning and consultation \\
& Experience \\
Management & Communication for the Fees \\
& Interfering parents or guardians \\
& Superficiality \\
& Double shift schooling \\
\hline
\end{tabular}

\subsection{Physical Structure}

Frequencies of the participants' responses to the question, "What do you think about the physical structure of the school you are working at?" are presented in Table 3 .

Table 3. Codings for physical structure

\begin{tabular}{lll}
\hline Codes & Participants & $\mathrm{f}$ \\
\hline I don't have a problem & $\mathrm{T} 6, \mathrm{~T} 8$ & 2 \\
I have a problem & $\mathrm{T} 1, \mathrm{~T} 2, \mathrm{~T} 3, \mathrm{~T} 4, \mathrm{~T} 5, \mathrm{~T} 7, \mathrm{~T} 9, \mathrm{~T} 10$ & 8 \\
The classroom is not capacious & $\mathrm{T} 4, \mathrm{~T} 5, \mathrm{~T} 9, \mathrm{~T} 10$ & 4 \\
There are no additional spaces (workplaces, garden, multipurpose hall, etc.) & $\mathrm{T} 3$ & 1 \\
There are no rooms for teachers. & $\mathrm{T} 2$ & 1 \\
There is not a toilet in the classroom. & $\mathrm{T} 7$ & 1 \\
Poor infrastructure & $\mathrm{T} 1$ & 1 \\
\hline
\end{tabular}


It is apparent that the participants have some problems with the physical structure of their schools, which underlines the importance of professional architectural designs for preschool buildings. Based on these findings, the sub-theme was titled "Architectural Design".

Some of the participant responses are presented below;

The biggest problem is that classrooms are too small and too crowded (T4).

We are having problems with the infrastructure, heating, plumbing and using the garden (T1).

The classrooms are too cramped, and the staff and toys take up most of the room. There is no space left to move (T9).

\subsection{Administrative Staff}

Frequencies of the participants' responses to the question, "What responsibilities principals and vice principals at your school should have?" are presented in Table 4.

Table 4. Codings for the administrative staff

\begin{tabular}{lll}
\hline Codes & Participants & $\mathrm{f}$ \\
\hline Clarifying job descriptions & T1, T5, T4 & 3 \\
Should better communicate with parents & T2, T9, T10, & 3 \\
Should focus on educational issues more & T2, T3, T6, T8 & 4 \\
\hline
\end{tabular}

As noted with the participant responses, principals and vice principals need to make the job definitions clear, have direct communication with parents and guide teachers for the educational issues more. Based on these findings, the sub-theme was titled "Leadership".

Some of the participant responses are presented below;

I think, teacher characteristics of the administration should be dominant and they should focus on things related to education instead of school budget. It does not seem possible for now. The work load is becoming heavier with the projects (T3).

Principals should have a better communication with teachers to improve the quality of the education. With the starting of schools, they lose focus because they often engage in activities that are not related to education (T10).

In addition to the administrative stuff, they should be in the classroom whenever needed. They should support teachers for teacher-parent conflicts. They should be kind but firm with parents.

I don't know how things are supposed to be because vice principals are deemed responsible for anything because principals are often away from the school for other tasks. I think school administration should have a better communication with us (T5).

\subsection{Teacher Groups}

Frequencies of the participants' responses to the question, "What do you think about the functioning of the teacher groups (all teachers in a school teaching the same subject) at your school? What kind of a work schedule do you follow?" are presented in Table 5.

Table 5. Codings for the teacher groups

\begin{tabular}{lll}
\hline Codes & Participants & $\mathrm{f}$ \\
\hline We do not have a problem with the teacher groups & T1, T4, T5, T7, T9 & 5 \\
Everyone is cooperating & T2, T3 & 2 \\
There is joint planning & T6, T8, T10 & 4 \\
\hline
\end{tabular}

All the preschool teachers in the sample stated that they were in cooperation with the others in their groups. Based on these findings, the sub-theme was titled "Joint Planning and Consultation".

Some of the participant responses are presented below;

We don't have a problem. We try to prepare and follow a work schedule that fits our initial surroundings and child-parent profiles in our school as much as possible (T4).

The goals and aims are set at the beginning of the academic year. These goals are adapted to and combined with 
the socioeconomic status of the social environment. If it is analyzed carefully with the teacher groups together to make a decision, there won't be a problem (T8).

We do not have a problem. We try to build a consensus on what should be done or what is needed. The head of the teacher group consults us and we do not have a problem while making our decisions. They want our support for the implementation of the decisions following the work schedule and we give our sport for financial and planning issues (T2).

\subsection{Support Staff}

Frequencies of the participants' responses to the question, "How do you evaluate the work of the support staff at your school? What are your criteria for hiring support staff?" are presented in Table 6.

Table 6. Codings for the support staff

\begin{tabular}{lll}
\hline Codes & Participants & $\mathrm{f}$ \\
\hline We do not have a problem & $\mathrm{T} 1, \mathrm{~T} 3, \mathrm{~T} 5$ & 3 \\
Unsatisfactory salary & $\mathrm{T} 2$ & 1 \\
Experience & $\mathrm{T} 4, \mathrm{~T} 6, \mathrm{~T} 7, \mathrm{~T} 8, \mathrm{~T} 10$ & 5 \\
Going beyond the job description & $\mathrm{T} 9$ & 1 \\
\hline
\end{tabular}

The participating teachers reported that they opt for hiring people who loves taking care of children with some experience and a good rapport with children. Based on these findings, the sub-theme was titled "Experience".

Some of the participant responses are presented below;

The biggest problem we have been experiencing with the support staff is that their salaries are paid from our budget that is from the fees received by the school administration. Sometimes it gets difficult to motivate people who work for a minimum wage. If they were permanent staff, they would be more comfortable and relieved (T2).

Sometimes the administration goes beyond their job descriptions. They think they are the boss and sometimes they behave towards parents in an unfriendly way (T9).

We want to have administrators who can work together with teachers in harmony and who loves spending time with children (T4).

We try to employ people for the support staff positions who have experience with childcare to meet children's hygiene, nutrition and special needs (T8).

\subsection{Collection of the Fees}

Frequencies of the participants' responses to the question, "Could you tell us about your experiences with the collection of fees? What are the biggest expenditure items on your school budget?" are presented in Table 7.

Table 7. Codings for the collection of the fees

\begin{tabular}{lll}
\hline Codes & Participants & $\mathrm{f}$ \\
\hline We contact the parents for fees & $\mathrm{T} 1, \mathrm{~T} 3, \mathrm{~T} 9$ & 3 \\
We are experiencing problems with collecting the fees & $\mathrm{T} 1, \mathrm{~T} 2, \mathrm{~T} 3, \mathrm{~T} 8, \mathrm{~T} 9, \mathrm{~T} 10$ & 6 \\
We do not have a problem & $\mathrm{T} 2, \mathrm{~T} 4, \mathrm{~T} 6, \mathrm{~T} 7$ & 4 \\
$\begin{array}{l}\text { The biggest expenditure items are nutrition, hygiene and salaries } \\
\text { of the support staff }\end{array}$ & $\mathrm{T} 1, \mathrm{~T} 3, \mathrm{~T} 6, \mathrm{~T} 7, \mathrm{~T} 8$ & 5 \\
\hline
\end{tabular}

Most of the teachers stated that they were experiencing problems with the collection of the fees and that they feel uncomfortable with talking to parents about financial issues. Based on these findings, the sub-theme was titled "Communication for the Fees".

Some of the participant responses are presented below;

It is us who follow up and collect the receipts of the fees from parents; we have to contact the parents, which is a problem. The biggest expenditure items are salaries and health insurance of the support staff and we do not have any budget left for other things (T1).

Financial difficulties (that the families are experiencing) result in setbacks. The biggest expenditure items are 
salaries of the staff, nutrition and hygiene (T8).

The fees are not paid on time and we often have to remind parents of the fees (T9).

As it is us who collect the fees from parents, we are being too familiar with them. Demanding money from parents makes them have a low opinion of teachers and results in a role conflict (T10).

\subsection{Environmental Factors}

Frequencies of the participants' responses to the question, "Does the socioeconomic status of the neighborhood where your school is located affect your work and activities in your classes? Do you do anything to improve the conditions?" are presented in Table 8.

Table 8. Codings for the environmental factors

\begin{tabular}{lll}
\hline Codes & Participants & $\mathrm{f}$ \\
\hline There are no environmental factors & T1, T6, T7, T8 & 4 \\
Parents interfere with the classroom activities & T2, T5 & 2 \\
The required materials are not supplied & T9, T10 & 2 \\
The problems with the payments of the fees & T3, T4 & 2 \\
\hline
\end{tabular}

The participating teachers expressed that the parents had been interfering with their activities, which is attributed to their socioeconomic status, and that they did not buy the materials required at school making their own decisions rather than following the teachers. Based on these findings, the sub-theme was titled "Interfering parents or guardians".

Some of the participant responses are presented below;

The socioeconomic status of the parents in our school is quite high. Most of them have a bachelors' or master's degree. However, this might be a problem as well because parents sometimes get too interfering leaving no space for teachers' decisions and they are often being a smart aleck (T2).

The socioeconomic status of the neighborhood is one of our problems. The parents in our school think they know the best. They even interfere with the ceremonies we prepare for National Sovereignty and Children's Day. I'm not sure whether they know the kind of education we receive at university and that we have to pass the Public Personnel Selection Examination to be a teacher (T5).

We often recommend them buy products or materials of high quality. The parents do not seem to care and they just buy whatever they want (T9).

\subsection{Supervision}

Frequencies of the participants' responses to the question, "What do you think about the supervision at your school?" are presented in Table 9.

Table 9. Codings for the supervision

\begin{tabular}{lll}
\hline Codes & Participants & $\mathrm{f}$ \\
\hline There is no supervision & $\mathrm{T} 1, \mathrm{~T} 3$ & 2 \\
There is little supervision & $\mathrm{T} 7$ & 1 \\
The supervisions are either superficial or irrelevant & $\mathrm{T} 2, \mathrm{~T} 9, \mathrm{~T} 10$ & 3 \\
The school administration is supervised & $\mathrm{T} 1, \mathrm{~T} 6, \mathrm{~T} 8$ & 3 \\
The supervisions are just fine & $\mathrm{T} 4, \mathrm{~T} 5$ & 2 \\
\hline
\end{tabular}

Most of the teachers complained that the supervisions are not carried out by professionals frequently enough. They also reported that the on-paper supervisions focus on procedures rather than content of the education and self-evaluation. Based on these findings, the sub-theme was titled "Superficiality".

Some of the participant responses are presented below;

I don't think the supervision of the preschools within the vocational high schools are not enough (T7).

We haven't been supervised for at least 4 years. The inspectors visiting our school just check the files and do not interview us. It is on paper and it does not investigate the content of the education we provide (T10).

The inspectors visiting preschools sometimes focus on irrelevant things (T9). 
They just check whether the documents are all there in the file. If they are fine, then the school becomes a perfect place. They don't look for the content and it's not a real supervision. What is preschool education? What do kids learn? They do not want to see the activities we do. What they do is to say the school is good if the papers are complete (T2).

\subsection{Work Hours}

Frequencies of the participants' responses to the question, "What do you think about the working hours at your school?" are presented in Table 10.

Table 10. Codings for the work hours

\begin{tabular}{lll}
\hline Codes & Participants & $\mathrm{f}$ \\
\hline Problems with full-day preschools & T2, T7 & 2 \\
Problems with half-day preschools & T3, T4, T8, T10 & 4 \\
No problems & T1, T5, T6 & 3 \\
There should be breaks & T9 & 1 \\
\hline
\end{tabular}

Most of the responses of the participants pointed out the problems with double shift schooling, such as lunch breaks being too short for the cleaning of the classrooms, the long and busy work hours and too much demand on the afternoon classes resulting in too crowded classrooms. Based on these findings, the sub-theme was titled "Double shift schooling".

Some of the participant responses are presented below;

I strongly believe that there should be no double shift preschools. It might have some advantages for teachers but it is very problematic for administrators. Most parents prefer the second group to the first one and the second group becomes much more crowded than the first group, which is not fair for teachers. It becomes much more tiring for the teachers of the second group (T3).

It is a problem for the cleaning of the classrooms because the lunch breaks in double shift schooling is too short. The working hours should be reduced for teachers (T4).

The hours children spend in preschool should be consistent with primary schools because receiving a half-day education in preschool is a problem for full-day primary school life.

\section{Results, Discussion and Recommendations}

\subsection{Results}

The teachers stated that there is a range of differences in the preschool education provided in schools because of not complying with the standards of the Ministry of National Education. In other words, there are remarkable differences even in the same preschool as it is too difficult to reach the same standards of quality due to some factors, such as teacher, curriculum, classroom environment, equipment, materials, etc.

The teachers reported that the physical structure of their preschools is poor because they think their classrooms are too cramped and crowded and there is no space left to move. They also told that there is not enough space for workplace, and they are having problems with the infrastructure, heating, plumbing and using the garden due to multi-storey designs.

The teachers expressed that they have no problems with working in teacher groups.

The teachers noted that they need to build a more guiding and enthusiastic communication with the school administrators.

Half of the teachers said that they have no problems with the collection of the fees, which is an administrative issue whereas the other half of the teachers reported that they are having problems with the delayed payments of the fees. The teachers were also uncomfortable with their responsibility to collect the fees which is given to them by the school administration.

The teachers wanted parents to trust them as experts of education and not to interfere with the school activities.

The teachers thought that the supervision should be carried out by some professionals and it should not be just the school principal who is responsible for the supervision.

The teachers found it tiresome working at full-day preschools without any breaks. However, the teachers working at half-day preschools reported many problems as well. 


\subsection{Discussion}

The poor physical structure of the preschools reported by the teachers emphasizes the need for a special architectural design that fits the principles and goals of preschool education.

The findings of the present study are consistent with Aktan, Kerem and Comert (2005) who surveyed 1760 preschool teachers and concluded that the physical environment is the biggest problem for teachers. Gol-Guven (2009) compared the quality of state-funded and private preschools indicated that most of the state-funded schools do not have a garden. All the participants of the current study work in the state-funded preschools and the biggest problem they have is the physical structure of their preschool buildings as well, such as lack of garden and playground equipment.

Dikici-Sigirtmac et al. (2011) reported that the lacking of educational materials and the cramped classrooms are some of the biggest problems with physical structure of school buildings. Ardic-Unuvar (2011) concluded that the school buildings do not have enough space and remarked that standards indicators should be develop to improve the physical quality of preschools.

NAEYC (2007; as cited in Gules, 2013) posited that durable and safe outdoor and indoor materials to support teachers and children's development should be available and they should be maintained and renewed on a regular basis. Demiroz, Karadag and Ulutas (2003) remarked that the school buildings should be designed considering the functional properties of learning environments, which are of utmost importance for interpersonal relationships.

The planning of the preschool buildings requires an interdisciplinary approach drawing from architecture, engineering, child development, education, psychology, economy, etc. A good planning should be done to provide children with high-quality education and the possible technical, architectural and economic problems should be foreseen and resolved in advance (Gules, 2013).

The teacher hoped that school principals and vice principals directly communicate with parents and be more active in home-school relationships. The teachers also call for a more active leadership, especially in educational issues. Although there was not a definition of school leadership on which all the teachers agreed on, "influence" and "process" were the two things where all the participants met. The first role of a leader is to get people unite around shared values and cooperate. Having a vision is another thing that a leader must have (Glover \& Bush, 2003). An effective leadership in the field of early childhood is to provide high-quality service and strive for development in society. This very leadership involves support parents and teachers by providing them with supervision and guidance for building and fostering personal and professional development (Rodd, 2006).

In most of the successful preschools, school administration works well because of a clear vision of pedagogy and curriculum shared by everyone working at the school. The administrative staff of such schools seems to work with a greater focus on preschool education, adult-child interactions and personnel trainings on early childhood education (Haile \& Hussein, 2017; as cited in Demir-Yildiz, 2018).

The administrators both in independent preschools and kindergartens share the same ideas on administration except for the communication process. As the administrators in independent preschools have less work load compared to the administrators of other schools, they have more time and opportunities to interact with the teachers they work with (Ebabil, 2015).

The leadership in schools definitely contributes to the quality of learning environments supporting teachers, parents and school staff (Aksoy, 2009). Leadership in schools is as influential as the school atmosphere and surroundings in supporting teachers' skills and motivations and plays a key role in improving learning outcomes as well (Pont, Nusche, \& Moorman, 2008).

All the preschool teachers stated that they were in cooperation with the others in their groups. They also expressed that they plan things together and benefit from the experiences of senior fellows without any problems. The fact that the preschool teachers did not have any disagreements over educational activities might be due to the resources on the Internet and the ones provided publishers that most teachers use. However, it should be noted that there are some conflicts between the teachers on details, such as the planning of the celebrations on special days and weeks, the decoration of classrooms and school, and end-of-year shows.

Kaya (2012) and Abbak (2008) pointed out that teachers often use "ready-made plans" instead of developing child-centered plans based on children's needs and interests, which suggests that the use of ready-made programs rather than developmentally appropriate programs reduces the discussion among teachers to a minimum. 
The participating preschool teachers reported that they opt for hiring people who loves taking care of children with some pedagogical experience and a good rapport with children as support staff. However, the lacking financial resources, thus not hiring people with the desired qualities is still a problem as evidenced by numerous studies.

People having the knowledge of child development and psychology and who can have a feeling for children in preschools as support staff are always needed but hard to find (Can \& Kilic, 2019). Demir-Yildiz (2018) revealed that the most important problems encountered in preschools reported by school administrators are the financial problems, the understaffed schools and the negative or ignorant parental attitudes, which is further supported by the findings of Sabanci, Altun and Ucar-Altun (2018), Demir-Yildiz (2018) and Ada, Kucukali, Akan and Dal (2014).

Zembat (2012) investigated the problems in the context of teachers-administrators and found that administrators are often remaining unconcerned with teachers' demands for support staff. Some school administrations try to compensate for the lack of support staff by resorting to other plans. Secer, Celikoz and Kayili (2010) reported that treating teacher trainees as if they were support staff during their internships is one of the biggest problems in schools.

The teachers expressed that they have been experiencing some problems with the collection of the fees. They said that they do not feel comfortable with talking to parents about financial issues and demanding money. One of the most common problems reported by teachers arises from the use of the fees collected from the parents to meet children's needs (Zembat, 2012). Can and Kilic (2019) found that most of the fees in preschools are not paid on a regular basis and that the fees are insufficient for the expenditures. They also observed that families are quite reluctant to pay the school fees. Most of the parents of preschoolers have high expectations from the preschools during this period. Financial support of the parents is needed and essential to meet these expectations and it seems impossible to provide high-quality education without that financial support (Bilgic, 2018).

Considering the economic status of the country, it is too difficult to make preschool education available to children without collecting fees. However, teachers are often assigned the task of collecting fees, which poses some big problems for teacher-parent relationships. The communication between parents and teachers, which is supposed to be built on education and learning, is damaged. This may sometimes result in parental confusions about teachers' role. Nevertheless, most teachers are supposed to collect the school fees from parents although it is the responsibility of the school administration.

Another problem that was reported by the teachers is parents interfering with the school activities, which was assumed to be a negative effect of high socioeconomic status. The teachers reported that parents did not follow teachers' recommendations when buying the materials required at school or did not buy anything at all.

The teachers who participated in Can and Kilic's (2019) study listed the problems they experienced with parents as follows: parents being too interfering with classroom activities, parents treating teachers as if they were babysitters, parents who are ignorant of the importance of preschool education, inconsistency between the attitudes of schools and families and parents not reinforcing children's behaviors taught at school, all of which are supported by the findings of Kaya (2013) and Zembat (2012) as well.

Husu and Tirri (2010) studied the conflicts that Finnish preschool teachers experienced and found out that the biggest problem the teachers have was with parents. Most of the parents expected the teachers to give preferential treatment to their children because they thought their children were special. The parents who wanted teachers to have a preferential attitude towards their children try to put pressure on teacher in different ways, such as making the teacher feel grateful and that she or he can pay it by showing special care of their children.

Similar instances are observed in Turkey as well. However, the ignorance of parents poses some problems for teachers' as much as high expectations. All these problems indicate poor home-school communication. Therefore, improving parent-school cooperation is very likely to contribute to the quality of education.

The preschool teachers remarked that the supervisions are superficial, nothing more than a mere formality, which gives no feedback, thus making no contributions to teachers' development. The preschools, which have the potential to shape future, should be carefully and adequately supervised (Turan, 2016). Supervision and guidance offer a dynamic process that aims to improve the quality of education. In addition, they play a key role in the revising teaching and learning activities in classrooms (Sullivan \& Glanz, 2000).

Research shows that teachers need feedback on their own performances. However, they are rarely offered knowledge and skills to support their professional development. They are often judged for their performances and advised to focus on professional development. Providing teachers with practical tools and knowledge and 
informing them of the positive results they might have would be the most useful thing to do (Akbaba, 2002; Akdag, 2014; Sullivan \& Glanz, 2000).

Research shows that the supervisions in preschools often fail to meet the needs of educators and support the scientific and instructional teaching-learning processes in schools. They also seem to pose particular problems, such as supervisors from branches other than early childhood education failing to offer guidance and counselling, and the use of irrelevant criteria for the supervisions (Ari \& Tugrul, 1996; Budak, 2009; Daglioglu, 2008; Haktanir, 2008; Topdal, 2004; Turan \& Yesilyurt, 2010; Yucel, 2009).

The teachers emphasized that the supervision and guidance in schools have definite weaknesses. First, they do not get informed about the results of the supervision and guidance processes and their voices are not heard and their ideas are not recognized anyway. In addition, the inspectors make no contributions to their personal and professional development because most of them do not have any experience with and knowledge of preschool education. They also complain that the supervisions are too short to understand the education in the classrooms, communicate with teachers or administrators, make classroom observations and evaluations, and reach conclusions based on the results and offer creative solutions. Lastly, teachers think that the inspectors of primary schools are not equipped with the skills and knowledge to understand teachers' needs and help them develop strategies that fit the expectations of the parents (Sabanci \& Omeroglu, 2013).

The preschool teachers expressed the problems with the work hours, specifically the problems with the double shift schooling, including the lunch break being too short, which results in the cursory cleaning of the classrooms, and the length of the work hours. Double shift schooling presents many problems, such as low-quality education, transportation problems, few students in the morning groups, children feeling drowsy, compressed activities, too short breaks, and no breakfast for children (Aktay, Isik, \& Gencsoy, 2019).

A classroom that is used by two teachers seems to reduce the sense of belonging among teachers as it prevents teachers from making permanent changes in their classrooms. Teachers cannot make their own decisions to design the learning centers, which might have a negative effect on quality of education. In addition, the cleaning of the classrooms is cursory because there is not enough time during the lunchbreaks. The support staff in the kindergartens as a part of primary schools has other tasks and therefore, it hinders the running of the tasks in preschools.

\subsection{Recommendations}

The following recommendations are proposed based on the results of the current study:

1) Special architectural designs for preschools based on the practical recommendations and opinion of teachers, administrators, parents and experts might improve the quality of preschool education to a great extent.

2) Principals and vice principals should have practical trainings on leadership, communication and management, etc.

3) Instead of using ready-made plans, activity plans should be prepared based on child and school dynamics.

4) The supervisions should be carried out more often and by experts in early childhood education to support teachers' professional development.

5) As it seems hard to find qualified support staff, certified training might be provided by Public Training Centers and the persons who have received such certificates might be given prioritiy for employment.

6) Schools might arrange orientations for parents to foster parent-school communication and help parents set realistic expectations.

\section{References}

Abbak, B. S. (2008). The examination of the family involvement activities in preschool training programme in terms of preschool teachers and parental view. Unpublished master thesis. Cukurova University Social Sciences Institute, Adana.

Ada, S., Kucukali, R., Akan, D., \& Dal, M. (2014). Management problems in preschool educational institutions. Middle Eastern \& African Journal of Educational Research, 12, 32-49.

Akbaba, S. (2002). The place and importance of vocational guidance in teacher training. Journal of National Education, 155, 21-31.

Akdag, Z. (2012). Beginning early childhood education teachers' career perceptions, expectations, concerns and 
their experiences in public schools. Unpublished doctoral thesis. Middle East Technical University, Ankara.

Aksoy, P. (2009). An examination on the quality of educational environments of preschool education institutions in terms of some variables (The sample in the city of Tokat). Unpublished Master Thesis. Ankara University, Institution of Educational Sciences, Ankara.

Aktan Kerem, E., \& Comert, D. (2005). Problems and solutions of the preschool education in Turkey. Journal of Educational Researchs, 21, 155-172.

Aktay, S., Isik, E., \& Gencsoy, E. (2019). Full Day Education or Dual Education (pp. 744-753)? III International Unlimited Education and Research Symposium.

Ardic Unuvar, U. (2011). Opinions of administrators, teachers and parents about quality development at the preschool education. Unpublished master thesis. Selcuk University, Social Sciences Institution, Konya.

Ari, M., \& Tugrul, B. (1996). Early childhood education. Journal of National Education, 132.

Aytac, T. (2000). School centered administration. Ankara: Nobel Publishing.

Bilgic, A. (2018). Views on kindergarten fees. Non-Thesis Master Project. Pamukkale University Institute of Educational Sciences, Denizli.

Budak, S. (2009). The views of primary education inspectors on the inspection of pre-school education institutions. 1st International Participatory Inspection Symposium, 22-23 June, Ankara.

Bute, M., \& Balci, F. A. (2010). Preschool Principals' Views on School Management Processes and Related Problems. Educational Administration: Theory and Practice, 4(16), 485-509.

Can, E., \& Kilic, S. (2019). Early childhood education: problems and solution suggestions. Journal of National Education, 48(1), 483-519.

Cinkir, S., \& Kuru Cetin, S. (2010). Teachers' opinions about the professional working relationships in schools. Educational Administration: Theory and Practice, 16(3), 351-376.

Creswell, J. W. (2007). Qualitative inquiry and research desing: Choosing among five approaches (2nd ed.). SAGE Publications.

Daglioglu, E. (2008). Early childhood education in our country. Journal of View on Education, 12, 45-53.

Demir, Y. C. (2018). Evaluating the difficulties in managing preschool educational institutions. Journal of Social Sciences of Mus Alparslan University, 6, 95-102.

Demiriz, S., Karadag, A., \& Ulutas, I. (2003). Educational environment and equipment in preschool education institutions. Ankara: Ani Publishing.

Dikici, S. A., Hos, G., \& Abbak, B. S. (2011). Solution methods and suggestions of preschool teachers towards inclusive education problems. Journal of Kirsehir Education Faculty, 12(4), 205-223.

Ebabil, D. (2015). Evaluation of the progress of the management processes in preschool educational institutions based on the views of managers and teachers. Unpublished master thesis. Canakkale On Sekiz Mart University Educational Sciences Institute, Canakkale.

Ekiz, D. (2007). Scientific research methods. İstanbul: Lisans Publishing.

Freeman, L. K., \& Brown, M. H. (2000). Evaluating the childcare director: The collaborative professional assessment process. Young Children, 55(5), 20-26.

Gol-Guven, M. (2009). Evaluation of the quality of early childhood classrooms in Turkey. Early Child Development and Care, 4(179), 437-451, https://doi.org/10.1080/03004430701217639

Gules, F. (2013). Determining quailty standards of physical environment in preschool education. Unpublished master thesis. Selcuk University, Social Sciences Institution, Konya.

Haktanir, G. (2008). The qualifications of preschool teachers. Journal of Views on Education, 12, 22-40.

Husu, J., \& Tirri, K. (2001). Teachers' ethical choices in sociomoral settings. Journal of Moral Education, 4(30), 361-375. https://doi.org/10.1080/03057240120094850

Katranci, M. (2014). Early childhood education and its importance. In S. Seven (Ed.), Introduction to early childhood education (pp. 1-14). Ankara: Pegem Academy Publishing.

Kaya, O. M. (2012). The evaluation of preschool teachers' children centred practices. Unpublished doctoral thesis. Gazi University Educational Sciences Institution, Ankara. 
Kuyucak, E. (2013). The expectations of preschool teachers from school managers and the level to meet teachers' expectations. Unpublished master thesis. Yeditepe University, Social Sciences Institution, Istanbul.

Miles, M, B., \& Huberman, A. M. (2016). Qualitative data analysis: An expanded sourcebook (2nd ed.). Thousand Oaks, CA: Sage.

Oguzkan, S., \& Oral, G. (1983). Early childhood education. İstanbul: National Education Publishing House.

Oktay, A. (1999). The magic years of life. Istanbul: Epsilon Publishing.

Oktay, A. (2006). Why is early childhood education important? How should it be implemented? Coluk Cocuk Journal, 11(65), 31-32.

Pont, B., Nusche, D., \& Moorman, H. (2008). Improving school leadership. Paris: OECD Publication. Retrivied May 05, 2020, from http://www.oecd.org/dataoecd/6/52/40545479.pdf

Rodd, J. (2006). Leadership in early childhood (3rd ed.). Australia: Allen \& Unwin.

Sabanci, A., Altun, M., \& Ucar, A. S. (2018). Problems encountered in pre-school education according to the views of school managers, teachers and parents. Educational Administration: Theory and Practice, 2(24), 339-385. https://doi.org/10.14527/kuey.2018.009

Sabanci, A., \& Omeroglu, M. (2013). Views of independent kindergarten teachers about inspection done by province inspectors. International Online Journal of Educational Sciences, 5(3), 685-700. https://doi.org/10.19160/e-ijer.77381

Secer, Z., Celikoz, N., \& Kayili, G. (2010). Problems in school practices in department of preschool teaching and solution suggestions. Journal of Yuzuncu Yil University Education Faculty, 1(7), 128-152.

Sullivan, S., \& Glanz, J. (2000). Supervision that improves teaching: Strategies and techniques (2nd ed.). California: Corwin Press.

Tok, E. (2002). Administration problems of the preschool educational institutions. Unpublished master thesis. Pamukkale University, Social Sciences Institution, Denizli.

Topdal, E. B. (2004). Supervising painting activity in kindergartens. National Education Journal, 164, 176-183.

Turan, F. (2016). Inspecting education activities in preschool education institutions. International Journal of Eurasia Social Sciences, 23(7), 94-119.

Turan, F., \& Yesilyurt, I. (2010). Problems encountered in the inspection of preschool education and developing inspection process. 2nd International Education Inspection Congress, 23-25 June.

Yildirim, A., \& Simsek, H. (2013). Qualitative research methods in social sciences (9th ed.). Ankara: Seckin Publishing.

Yucel, H. (2009). Inspecting of preschool teachers. Unpublished master thesis. Cumhuriyet University Social Sciences Institution, Sivas.

Zembat, R. (2012). A Study on preschool teachers' perceived conflict with school administrators, colleagues and parents. Education and Sciences, 163(37), 203-215.

\section{Copyrights}

Copyright for this article is retained by the author, with first publication rights granted to the journal.

This is an open-access article distributed under the terms and conditions of the Creative Commons Attribution license (http://creativecommons.org/licenses/by/4.0/). 